\title{
Indikator Kesejahteraan Petani melalui Nilai Tukar Petani (NTP) dan Pembiayaan Syariah sebagai Solusi
}

\author{
Cut Muftia Keumala
}

Sekolah Tinggi Ilmu Ekonomi (STIE) Lhokseumawe

email: cut.muftia@gmail.com

\section{Zamzami Zainuddin}

Universitas Islam Negeri Ar-Raniry Banda Aceh email: zem.aceh@gmail.com

\begin{abstract}
As an agricultural country, attention to the welfare of farmers in Indonesia is considered very strategic. One of the measuring tools for farmers' welfare that is used today is Farmer's Exchange Rate (FER). This study aims to examine and explore some of the problems with the exchange rate experienced by farmers, including; Farmer's Exchange Rate (FER) in identifying the welfare of farmers, determining the increase and decrease of Farmer Exchange Rate (FER) in Indonesia; and the potential of Islamic financing in providing solutions for the welfare of farmers. The results show that the increase in FER is not always good. Determination of the increase and decrease rice farmers' exchange rates are productivity, grain prices, prices of consumer goods, and prices of fertilizers, the exchange rate of farmers on food and nonfood consumption, and production costs. Shariah schemes can be used as a new alternative to help the interest-free and profit-sharing agricultural sector.
\end{abstract}

Keywords: Welfare; Farmer's Exchange Rate (FER); Sharia Financing.

Abstrak: Sebagai negara agraris perhatian terhadap kesejahteraan petani di Indonesia dinilai sangat strategis. Salah satu alatukur kesejahteraan petani yang digunakan saat ini adalah Nilai Tukar Petani (NTP). Penelitian ini bertujuan untuk mengkaji dan menggali beberapa permasalahan terhadap nilai tukar yang dialami petani, antara lain; Nilai Tukar Petani (NTP) dalam mengindentifikasi kesejahteraan petani, penentu peningkatan dan penurunan Nilai Tukar Petani (NTP) pangan di Indonesia; dan potensi pembiayaan syariah dalam memberikan solusi untuk mensejahterakan petani. Hasil penelitian menunjukkan bahwa Kenaikan NTP tidak selalu baik. Penentu terjadinya kenaikan dan penurunan nilai tukar petani padi adalah produktivitas, harga gabah, harga barang konsumsi, dan harga pupuk, nilai tukar petani terhadap konsumsi makanan dan nonmakanan, serta biaya produksi. Skim syariah dapat dijadikan alternatif baru untuk membantu sektor pertanian yang bebas bunga dan berdasarkan bagi hasil.

Kata Kunci: Kesejahteraan; Nilai Tukar Petani (NTP); Pembiayaan Syariah.

Economica: Jurnal Ekonomi Islam - Volume 9, Nomor 1 (2018) 


\section{Pendahuluan}

Salah satu sumber kebutuhan utama manusia berasal dari sektor pertanian. Banyak pekerja berasal dari sektor pertanian yang semestinya perlu dilindungi dan disejahterakan karena mereka telah berjasa dalam hal pemenuhan kebutuhan hidup orang banyak. Namun kenyataannya di Indonesia petani malah seringkali dirugikan dengan pendapatan mereka yang kecil. Naiknya harga pangan saat ini terutama beras memiliki kaitan dengan nilai yang harus dibayar petani yang jumlahnya lebih tinggi dari nilai yang diterima oleh para petani. Karena itu kita harus menghadapimya dengan bijak, realistis, positif dan optimis agar risiko ke depan dapat diminimalisir seminimal mungkin terutama pada risiko jangka panjang (long term risk) yang tentunya mengancam kesejahteraan petani dan masyarakat ekonomi. Nilai tukar petani pangan merupakan indikator kesejahteraan petani. Dalam mengukur tingkat kesejahteraan petani, instrumen yang digunakan salah satunya adalah Nilai Tukar Petani (NTP). Peningkatan NTP mengindikasi terjadinya peningkatan kesejahteraan petani, begitu juga sebaliknya.

NTP berkaitan dengan daya beli petani dalam hal membiayai kebutuhan rumah tangganya. Jika pendapatan petani lebih besar dari kenaikan harga produksi pertanian dan berdampak pada daya belinya, hal ini akan mengindentikasi bahwa kemampuan petani menjadi lebih baik atau terjadi kenaikan pendapatannya. Meningkatkan kesejahteraan petani dan kinerja sektor pertanian memerlukan pembiayaan yang tidak hanya dapat menolong petani untuk mengolah pertaniannya, tetapi juga dapat menolong mereka dalam hal pelunasannya. Mengingat arti peran kredit dalam pembangunan sektor pertanian, telah mendorong pemerintah untuk menjadikannya istrumen kebijakan penting. Menurut Tampubolon (Tampubolon 2002), kredit dinggap salah satu alat untuk memutuskan "lingkaran setan" dari pendapatan rendah, kemampuan memupuk modal rendah, kemampuan membeli sarana produksi rendah, produktivitas usaha tani rendah, dan 
pendapatan petani rendah. Namun dari pengalaman selama ini menunjukkan bahwa efektivitas kebijakan kredit di Indonesia belum optimal.

Hal ini terbukti dari masih lemahnya pemberian modal untuk para petani dan terjadi kredit macet dikarenakan penunggakan kredit program. Ada tiga permasalahan yang bisa mengancam kesejahteraan petani atas ketidakefektivitas kredit (Ilham, Siregar, and Priyarsono 2016). Pertama, kredit berbasis bunga tetap di mana menjadikan bunga tetap sebagai harga tetap dari dana yang dipinjam dan harus dikembalikan ketika jatuh tempo. Padahal sektor pertanian memiliki risiko yang tinggi terhadap jumlah produktivitas serta fluktuasi harga yang relatif tinggi. Jika petani mengalami kegagalan baik itu karena rusaknya panen atau rendahnya harga pasar maka yang terjadi mereka tidak mampu membayar pinjaman sehingga pada akhirnya terjerat hutang yang makin besar jumlahnya karena sistem yang berbasis bunga.

Kedua, adanya gap antara peminjam dan pemberi pinjaman, di mana peminjam langsung terjun ke sektor riil sedangkan pemberi pinjaman berada pada sektor moneter. Gap yang terjadi bahwasanya risiko kegagalan usaha hanya dibebankan pada si peminjam, sementara si pemberi pinjaman akan tetap memeroleh keuntungan sebesar suku bunga yang ditetapkan. Ketiga, pembiayaan saat ini lebih diberdayakan kepada sektor nonpertanian (jasa dan industri). Jika diberdayakan pada sektor pertanian, maka cenderung lebih over estimate. Dan apabila hal ini dipaksakan maka akan menyusahkan para petani untuk melakukan pinjaman sesuai dengan jumlah yang dibutuhkan. Sebagai solusi, untuk menjamin kesejahteraan para petani maka harus ada jalur pembiayaan alternatif yang sesuai dengan sektor pertanian.

Salah satu modelnya adalah model pembiayaan berbasis syariah di mana diharapkan dapat membantu para petani untuk melakukan pembiayaan yang lebih aman, nyaman, dan terkendali. Nilai tukar petani ini merupakan salah satu alat ukur kesejahteraan petani, sedangkan pembiayaan syariah menjadi 
solusi pinjaman bagi para petani yang ingin meminjam demi meningkatkan produktivitas tani.

Terdapat beberapa penelitian terdahulu yang telah mengkaji tentang Nilai Tukar Petani (NTP) sebagai indikator kesejahteraan petani. Penelitian yang dilakukan oleh Ruauw (Ruauw 2010) menyimpulkan bahwa semakin tinggi NTP, relatif semakin sejahtera tingkat kehidupan petani yang akan membawa dampak baik untuk pertumbuhan ekonomi. Dilihat dari pasca kenaikan harga BBM Oktober 2005, NTP merosot sebesar 2,39\%, artinya indeks harga yang dibayar petani lebih besar dari yang diterima petani, sehingga terdapat hubungan positif antara kenaikan BBM dengan penurunan NTP yang menyebabkan turunya kesejahteraan petani.

Penelitian Herdayana juga melaporkan bahwa peningkatan NTP sebesar satu persen akan meningkatkan produksi 0,02 persen, dan peningkatan NTP sebesar satu poin akan meningkatkan pendapatan Rp1.285,8. Jadi, meningkatnya NTP yang dilihat dari produksi dan pendapatan akan meningkatkan kesejahteraan petani (Hendayana 2002).

Selanjutnya, penelitian Ashari dan Saptana (Ashari and Saptana 2005) juga menyebutkan bahwa kredit program yang memakai sistem bunga menunjukkan hasil yang kurang memuaskan seperti membengkaknya hutang petani serta kredit macet sehingga menyebabkan kesejahteraan petani pun berkurang. Lembaga pembiayaan syariah (nonbunga) cukup prospektif untuk dijadikan sebagai salah satu alternatif penguatan modal pada usaha di sektor pertanian. Penelitian lainnya juga menyebutkan bahwa secara rataan perubahan harga padi yang dihasilkan atau dijual petani berpengaruh positif terhadap kenaikan NTP yang artinya kenaikan harga padi akan meningkatkan NTP (Rachmat 2000).

Secara spesifik, penelitian ini bermaksud untuk untuk mengetahui model nilai tukar petani dalam mengindentikasikan kesejahteraan petani, isu-su kritis dalam menentukan peningkatan dan penurunan Nilai Tukar Petani 
Indikator Kesejahteraan Petani melalui Nilai Tukar Petani (NTP)...

Pangan (NTP) di Indonesia, dan potensi pembiayaan syariah dalam memberikan solusi untuk mensejahterakan petani dalam meningkatkan produksi (NTP).

\section{Landasan Teori}

\section{Nilai Tukar Petani (NTP)}

Nilai Tukar Petani (NTP) adalah perbandingan antara indeks harga yang diterima petani (IT) dengan indeks harga yang dibayar petani (IB) dalam persentase. Nilai tukar petani juga merupakan suatu indikator yang digunakan untuk mengukur tingkat kesejahteraan atau kemampuan daya beli petani (Badan Pusat Statistik 2011).

Secara umum ada tiga pengertian Nilai Tukar Petani (Ruauw 2010). Pertama, jika NTP $>100$, berarti petani mengalami surplus, harga produksi naik lebih besar daripada konsumsinya. Pendapatan petani naik lebih besar dari pengeluarannya. Dengan demikian tingkat kesejahteraan petani lebih baik dibanding tingkat kesejahteraan petani sebelumnya. Kedua, NTP = 100, berarti petani mengalami impas/break even. Kenaikan atau penurunan harga barang produksinya sama dengan persentase kenaikan atau penurunan harga barang konsumsinya. Tingkat kesejahteraan petani tidak mengalami perubahan. Ketiga, NTP < 100, berarti petani mengalami defisit. Kenaikan harga barang produksinya relatif lebih kecil dibandingkan dengan kenaikan harga barang konsumsinya. Tingkat kesejahteraan petani pada suatu periode mengalami penurunan dibanding tingkat kesejahteraan petani periode sebelumnya.

Adapun pembentukan Nilai Tukar Petani adalah sebagai berikut:

Pertama, konsep pertukaran. Nilai tukar barter didefinisikan sebagai rasio dari harga pertanian terhadap harga produk nonpertanian (Rachmat 2000).

$$
\text { NTB }=\text { Px/Py }
$$


di mana:

NTB = Nilai tukar Barter Pertanian

Px = Harga Komoditas Pertanian

Py = Harga Produk Non-Pertanian

Konsep nilai tukar ini mampu mengindentifikasi perbandingan harga relatif dari komoditas pertanian tertentu terhadap harga produk yang dipertukarkan. Dapat dianalogikan seperti pada harga sebutir telur 10-15 tahun yang lalu, adalah sepadan nilainya dengan ongkos transportasi pulang pergi ke suatu tempat. Kini untuk harga yang harus dibayar untuk transportasi ke tempat yang sama adalah sebesar 5 butir telur. Jadi harga satu butir telur nilainya tidak relevan lagi dengan nilai sekarang karena telah terjadinya inflasi. Analogi harga telur tersebut menggambarkan bahwa nilai tukar harga komoditas pertanian misalnya telur mengindentikasikan daya tukar komoditas pertanian terhadap barang yang dipertukarkan seperti barang faktor produksi dan konsumsi.

Kedua, konsep faktorial. Nilai tukar dalam konsep ini didefinisikan sebagai rasio harga pertanian terhadap harga nonpertanian dikalikan dengan produktivitas pertanian (Rachmat 2000).

$\mathrm{NTF}=\mathrm{Px} / \mathrm{Py} * \mathrm{Z}$

di mana:

$\mathrm{Z} \quad$ = Produktivitas pertanian

Konsep ini mampu mengidentifikasi pengaruh perubahan teknologi dari komoditas dan produk tertentu yang dipertukarkan. Namun konsep ini terbatas kepada komoditas dan produk tertentu dan tidak dapat menjelaskan kemampuan seluruh komoditas/produk yang dipertukarkan.

Ketiga, konsep pendapatan. Konsep pendapatan (Nilai Tukar Pendapatan) merupakan perbaikan dari konsep nilai tukar faktorial. Nilai Tukar Pendapatan (NTI) merupakan daya ukur dari nilai hasil komoditas 
pertanian yang dihasilkan petani per unit (hektar) terhadap nilai korbanan untuk memproduksi hasil tersebut (Suntoro et al. 2014).

$$
\text { NTI }=\text { PxQx } / \text { PyQy }
$$

Dengan demikian, NTI menggambarkan tingkat profitabilitas dari usaha tani komoditas tertentu. Namun demikian, NTI hanya menggambarkan nilai tukar dari komoditas tertentu, belum mencakup keseluruhan komponen pendapatan petani dan komponen pengeluaran petani.

Keempat, Nilai Tukar Subsisten (NTS) yang menggambarkan daya ukur dari pendapatan total usaha pertanian terhadap pengeluaran total petani untuk kebutuhan hidupnya (Suntoro etal. 2014). Pendapatan usaha pertanian merupakan penjumlahan dari seluruh nilai produksi komoditas pertanian yang dihasilkan petani. Pengeluaran petani merupakan penjumlahan dari pengeluaran untuk konsumsi rumah tangga dan pengeluaran untuk biaya produksi usaha tani. Dengan demikian NTS menggambarkan tingkat daya tukar/ daya beli dari pendapatan usaha pertanian dari usaha tani terhadap pengeluaran rumah tangga petani untuk kebutuhan hidupnya yang mencakup pengeluaran konsumsi dan pengeluaran untuk biaya produksi.

Secara konsepsi, NTP mengukur daya tukar dari komoditas pertanian yang dihasilkan petani terhadap produk yang dibeli petani untuk keperluan konsumsi dan keperluan dalam memproduksi usaha tani. Nilai Tukar Petani yang rendah menyulitkan mereka dalam memenuhi kebutuhan pokok yang lain. Persoalannya adalah persoalan hidup dan mati bagi petani yang punya tanah dan hidupnya hanya dari hasil-hasil pertanian (Winangun 2004).

\section{Kesejahteraan Petani}

Petani merupakan sumber daya insani yang memiliki daya yang tinggi untuk mensejahterakan masyarakat. Tanpa bantuan petani manusia akan sulit untuk bertahan hidup. Karenanya keberadaaan petani sangat penting bagi kehidupan manusia. Menurut Sunarti dan Khomsan (Sunarti and 
Khomsan 2006), kesejahteraan petani bisa terealisasi melalui pendapatan mereka yang meningkat, minimnya terjadi kegagalan panen, produktivitas meningkat, dan harga gabah dibeli tinggi. Sebaliknya, faktor-faktor yang menyebabkan para petani masih belum merasakan kesejahteraan dan belum juga maju disebabkan beberapa faktor, antara lain: (1) Harga gabah dibeli murah oleh para tengkulak; (2) Kurangnya pasokan subsidi pupuk dan benih tanaman oleh pemerintah; (3) Beras diimpor oleh negara tetangga; (4) Sulitnya pinjaman untuk petani. Salah satu indikator yang dianggap penting untuk mengetahui tinggi rendahnya kesejahteraan petani dapat dilihati melalui Nilai Tukar Petani (NTP). Semakin tinggi nilai tukar pertanian, maka semakin tinggi pula tingkat kesejahteraan petani (Darwanto 2005).

\section{Pembiayaan Syariah}

Salah satu problem utama dalam pembangunan di sektor pertanian adalah aspek permodalan yang lemah. Sebagai unsur penting dalam meningkatkan produksi dan taraf hidup masyarakat pedesaan, ketiadaan modal dapat membatasi ruang gerak sektor ini. Karakteristik usaha pertanian yang mengandung banyak risiko menyebabkan minat lembaga pembiayaan untuk mendanai usaha sektor ini relatif rendah. Syukur et al. (Syukur, Sumaryanto, and Muslim 1993) mengemukakan bahwa proporsi kredit pertanian dan sarana pertanian di Jawa Barat dan Sumatera Barat, misalnya, masih di bawah 3 persen dari total penyaluran kredit perbankan. Angka ini jauh di bawah pembiayaan untuk sektor perindustrian, perdagangan, restoran dan hotel, pengangkutan, dan sektor lain.

Tidak dipungkiri bahwa telah ada beberapa upaya pemerintah untuk mengatasi permasalahan tersebut, antara lain dengan meluncurkan beberapa kredit program untuk sektor pertanian. Namun, kredit program yang berbasis bunga tersebut tidak memberikan hasil yang memuaskan, bahkan cenderung menimbulkan permasalahan baru seperti membengkaknya hutang petani serta kemungkinan terjadinya kredit macet. 
Oleh karena itu, perlu mencari alternatif baru untuk membantu sektor pertanian. Salah satunya dapat diatasi dengan skim syariah yang berbeda dengan kredit. Pembiayaan syariah ini bebas bunga dan berdasarkan bagi hasil (Pasaribu et al. 2007). Maksud dari pembiayaan berdasarkan prinsip syariah adalah penyediaan uang atau tagihan yang dipersamakan dengan itu berdasarkan persetujuan atau kesepakatan antar bank dengan pihak lain yang mewajibkan pihak yang dibiayai untuk mengembalikan uang atau tagihan tersebut setelah jangka waktu tertentu dengan imbalan dan bagi hasil (Antonio 2001).

Menurut sifat penggunaannya, pembiayaan dapat dibagi menjadi dua hal. Pertama, pembiayaan produktif, yaitu pembiayaan yang ditujukan untuk memenuhi kebutuhan produksi dalam arti luas, yaitu untuk peningkatan usaha baik usaha produkasi, perdagangan, maupun investasi. Kedua, pembiayaan konsumtif, yaitu pembiayaan yang digunakan untuk memenuhi kebutuhan konsumsi.

Menurut keperluannya, pembiayaan produktif dapat dibagi menjadi dua. Pertama, pembiayaan modal kerja, yaitu pembiayaan untuk memenuhi kebutuhan Peningkatan produksi dan keperluan perdagangan. Kedua, pembiayaan investasi, yaitu untuk memenuhi kebutuhan barang-barang modal serta fasilitas-fasilitas yang erat kaitannya dengan itu sebagaimana terlihat pada gambar 1.

Gambar 1. Jenis-jenis Pembiayaan

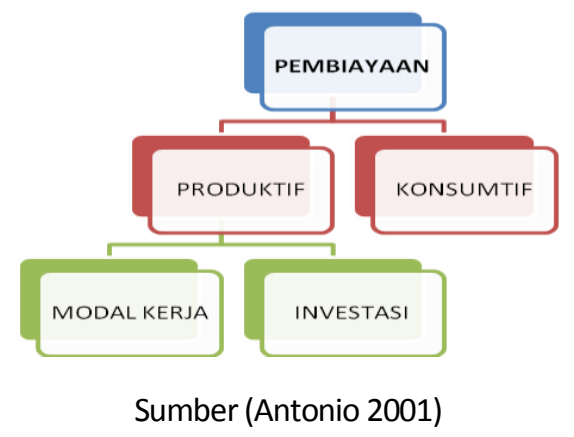

Economica: Jurnal Ekonomi Islam - Volume 9, Nomor 1 (2018) 
Bagi seorang Muslim, peminjaman uang yang disertakan bunga walaupun itu kecil tetap saja masuk ketegori riba yang dilarang dalam Islam karena dapat merugikan pihak peminjam. Karena itu, para ahli dalam bidang ekonomi syariah membentuk suatu pembiayaan untuk menolong para petani melalui jalan yang tidak melanggar norma-norma Islam.

Di antara model pembiayaan yang dapat digunakan adalah bai' salam atau salam (in front payment sale). Bai' salam adalah proses jual beli yang dilakukan di mana penjual setuju men-supply sejumlah barang dengan kualitas dan karakteristik tertentu pada tanggal tertentu di masa yang akan datang kepada pembeli. Sementara pembeli membayar harga jual secara penuh saat terjadinya transaksi. Biasanya harga yang disepakati lebih rendah dari harga pasar. Hal tersebut dimaksudkan agar kepentingan pembeli tidak terabaikan (Ariffin, Archer, and Karim 2009).

Bai' salam berbeda dengan praktek ijon yang telah dikenal dan banyak dipraktikkan masyarakat pedesaan sampai saat ini. Dalam sistem ijon sama sekali tidak ada kejelasan tentang kuantitas barang yang diperjualbelikan dan bersifat spekulatif. Sementara pada bai' salam disyaratkan harus adanya kejelasan tentang kuantitas, kualitas barang serta waktu pembayarannya

Ba'i salam sangat bermanfaat bagi petani. Tidak hanya masyarakat muslim saja yang berminat pada proses ini, namun juga nonmuslim yang melihat pembiayaan ini lebih baik dan efektif daripada memberi bunga. Konsep dari pembiayaan ini dapat diilustrasikan sebagai berikut. Seorang petani mampu menghasilkan 10 ton kentang melalui lahan pertaniannya. Biaya untuk memproduksi kentang adalah Rp3.000,00/kg, sedangkan harga kentang di pasaran adalah Rp5.000,00/kg. Dengan konsep salam, bank syariah akan membeli hasil tani tersebut di muka dengan harga Rp4.000,00/kg. Sehingga pembeli dan petani mendapatkan keuntugan sebesar Rp1.000,00/kg atau 10 juta (dikalikan 10 ton). Dengan begitu, petani mendapatkan dana segar untuk melakukan pertanian dan mencukupi kebutuhan sehari-hari selama kurun waktu pertanian tersebut. Pembiayaan 
lainnya bisa berupa pinjaman biasa yang berupa nonbunga atau profit and lost sharing.

\section{Hasil dan Pembahasan}

\section{Nilai Tukar Petani (NTP) dan Kesejahteraan Petani}

Angka NTP yang tercipta sejatinya merupakan indikator tingkat daya beli masyarakat/petani dan hal ini yang bisa digunakan untuk mengukur kesejahteraan petani dari sisi daya beli terhadap harga barang nonpertanian. NTP yang naik berarti daya beli petani meningkat, tetapi bukan berarti tingkat kesejahteraan petani secara nominal meningkat. Semakin tinggi NTP, relatif semakin sejahtera tingkat kehidupan petani yang akan membawa dampak yang baik terhadap pertumbuhan ekonomi. Misalnya, kenaikan nilai tukar petani pada masa krisis disebabkan karena harga komoditas ekspor hasil perkebunan rakyat naik drastis pada masa itu. Perubahan kurs mata uang yang cepat pada tahun 1998, membuat produk pertanian Indonesia sangat murah di luar negeri namun naik tajam di dalam negeri.

Petani, terutama pada subsektor perkebunan rakyat mendapatkan keuntungan dari krisis tersebut. Melalui keuntungan itulah petani kemudian dapat mengembangkan usaha pertanian yang dilakukannya sehingga dapat memenuhi kebutuhan hidup petani dan keluarganya dengan lebih baik.

Dampak apabila nilai tukar petani mengalami penurunan Nilai IT (indeks harga yang diterima petani) yang lebih kecil dibandingkan dengan IB (indeks harga yang dibayar petani), menyebabkan NTP cenderung turun. Penurunan ini disebabkan karena petani tanaman pangan dan tanaman perkebunan rakyat hanya mampu menjual hasil produksinya dengan tingkat kenaikan harga yang tipis dibandingkan dengan harga bulan sebelumnya. Dan pada saat yang sama, harga rata-rata barang dan jasa untuk konsumsi rumah tangga pedesaan maupun keperluan produksi pertanian mengalami kenaikan. Menurunnya nilai tukar petani, berarti bahwa kesejahteraan petani 
relatif turun, yang membawa dampak bertambahnya tingkat kemiskinan sebagai salah satu penghambat pertumbuhan ekonomi suatu negara.

Angka NTP yang tercipta menggambarkan kesejahteraan petani makin baik bila posisi daya tukar tinggi atas barang konsumsi dan faktor produksi. Faktor pemicunya adalah produktivitas yang stabil/meningkat dan permintaan tinggi. Menurut Ristek, selama ini peningkatan produksi beras tidak diikuti dengan peningkatan kesejahteraan, Nilai Tukar Petani tidak menjadi lebih baik. Berdasarkan data EPS, tanaman pangan pada juni 2008 adalah 97,14. Khusus untuk petani padi , NTP-nya lebih rendah yakni 93,95 (NTP 2007=100). Maknanya saat produksi beras naik 5,46\%. Kesejahteraan petani malah turun 6,05\% (Ristek 2009).

Berdasarkan laporan perkembangan Nilai Tukar Petani (NTP) Provinsi Aceh bulan Maret yang dikeluarkan BPS Aceh (2 April 2012). NTP Provinsi Aceh bulan Maret 2012 sebesar 104,52 atau mengalami penurunan sebesar 0,53 persen dibandingkan bulan sebelumnya. Naik-turunnya NTP Aceh dianggap sebagai hal yang "biasa" saja, dikarenakan hanya menggambarkan dinamika dari harga yang diterima maupun harga yang dibayarkan oleh petani. Namun penurunan NTP Aceh kali ini terasa lebih "istimewa". Di saat harga-harga bahan kebutuhan pokok mengalami kenaikan ternyata kemampuan/daya beli petani malah menurun.

Kondisi ini tentu ini menimbulkan tanda tanya besar, NTP yang menjadi salah satu indikator untuk melihat tingkat kemampuan/daya beli petani tidak merangkak naik ditengah-tengah kenaikan harga-harga bahan kebutuhan pokok yang sejatinya dihasilkan oleh petani itu sendiri. Idealnya, kenaikan harga-harga bahan pokok berkorelasi positif dengan peningkatan kemampuan/daya beli petani (Saputra 2012).

Seperti yang dijelaskan sebelumnya, hal ini dikarenakan eksploitasi besar oleh pemilik modal kepada petani, sehingga mereka terpaksa menjual gabahnya dengan harga yang sangat murah. Jika hal ini tidak diperhatikan dan 
tidak ditindaklanjuti, maka dikhawatirkan petani akan lari dari pekerjaannya atau menghilangnya profesi petani. Belum lagi masalah subsidi bibit unggul dan pupuk yang tidak diberikan tepat waktu. Inilah yang menyebabkan indikator terhadap nilai tukar petani semakin menurun. Tapi perlu diketahui nilai tukar petani tidak keseluruhan dapat mengindentikasikan kesejahteraan petani, seperti hasil dari penelitian Rachmat (Rachmat 2000) di mana diperoleh data bahwa nilai tukar petani tidak dapat mengukur kesejahteraan petani secara nominal.

NTP naik tidak selalu baik, kenaikan NTP pada sektor pangan perlu dilihat apakah produktivitas hasil komoditas memang mengalami kenaikan signifikan. Bisa jadi malah kebalikannya, terjadi penurunan produksi akibat anomali cuaca yang mengganggu produksi.

Pada intinya nilai tukar petani sangat berpengaruh terhadap pemenuhan kebutuhan petani karena apabila nilai tukar petani rendah maka petani tidak dapat memenuhi kebutuhan hidupnya yang layak. Jika nilai tukar petani tinggi, maka petani akan mengalami kesejahteraan. Jadi tinggi rendahnya rasio (nilai tukar petani) dapat dijadikan sebagai indikator tingkat kesejahteraan petani, meskipun belum seluruhnya benar. Sebab kesejahteraan petani bersifat kualitatif sedangkan NTP merupakan ukuran kuantitatif (Darwanto 2005).

\section{Penentu Peningkatan dan Penurunan Nilai Tukar Petani (NTP) Pangan di Indonesia}

Seperti yang telah dijelaskan sebelumnya bahwa nilai tukar petani yang merupakan indikator kesejahteraan petani bisa dilihat dari indeks harga yang diterima petani dengan indeks harga yang dibayar petani. Indeks harga yang diterima petani dilihat dari hasil produktivitas petani baik itu pada sektor pertanian, perkebunan, perikanan, dan perternakan. Sedangkan indeks harga yang dibayar petani dilihat dari biaya yang dikeluarkan untuk produksi (modal) dan dari biaya yang dikeluarkan untuk konsumsi rumah tangga. 
Adapun penentu peningkatan dan penurunan nilai tukar petani, khususnya petani padi, adalah sebagai berikut. Pertama, produktivitas yang dihasilkan petani. Kedua, rendah/ tingginya harga gabah yang diberikan untuk petani. Ketiga, harga barang-barang konsumsi rumah tangga baik pangan, papan dan sandang. Keempat, harga pupuk yang digunakan sebagai salah satu alat produksi.

Keempat hal di atas merupakan penentu dalam peningkatan atau penurunan nilai tukar petani. Dalam penelitian Hendayana dijelaskan bahwa produktivitas dan harga gabah berpengaruh secara positif, sedangkan harga pupuk berpengaruh secara negatif. Harga gabah mempunyai elastisitas positif terbesar sedangkan dari berbagai jenis pupuk yang digunakan, harga pupuk urea mempunyai elastisitas negatif terbesar (Hendayana 2002).

Dengan pola hubungan tersebut dapat dikatakan bahwa semakin tinggi produktivitas usaha tani semakin tinggi nilai tukar petani. Hal yang sama berlaku juga untuk harga gabah yaitu semakin tinggi harga gabah yang dijual petani akan semakin baik nilai tukar petani. Sebaliknya untuk harga pupuk, dapat dikatakan bahwa semakin tinggi harga pupuk semakin rendah nilai tukar petani. Jadi untuk meningkatkan nilai tukar petani diperlukan upaya menyeluruh berupa intervensi dalam hal kebijakan harga output (gabah) dan harga input terutama pupuk.

Sedangkan penelitian Rachmat (Rachmat 2000) menjelaskan beberapa faktor yang menentukan nilai tukar petani yaitu:

Pertama, Nilai Tukar Petani terhadap Konsumsi Makanan (NTP-Mak). Nilai tukar ini menggambarkan daya beli masyarakat terhadap harga produk makanan yang dibeli petani. Produk konsumsi makanan mencakup padipadian, daging-ikan-unggas, sayur-sayuran, usu-telur-lemak, buah-buahan, dan kelompok makanan minuman lainnya. Hasil penelitian myang diperoleh, bahwa NTP-Mak berpengaruh secara negatif terhadap nilai tukar petani. Jika 
NTP-Mak meningkat/relatif mahal akan menyebabkan NTP khususnya tanaman pangan menjadi turun.

Kedua, Nilai Tukar Petani terhadap Konsumsi Nonmakanan (NTPNMak). Nilai tukar ini menggambarkan daya beli masyarakat terhadap harga produk non-makanan yang dibeli petani. Perkembangan harga-harga produk nonmakanan merupakan harga yang terbentuk dari pengeluaran untuk perumahan, tempat tinggal, dan aneka jenis barang dan jasa. Sama halnya dengan NTP-Mak, NTP-NMak berpengaruh secara negatif terhadap nilai tukar petani. Jika NTP-Mak meningkat/relatif mahal akan menyebabkan NTP khususnya tanaman pangan menjadi turun.

Ketiga, Nilai Tukar Petani terhadap Biaya Produksi (NTP-BP). Nilai tukar ini menggambarkan daya beli antara komoditas yang dihasilkan petani terhadap biaya produksi. Komponen biaya produksi dikelompokkan dalam input pupuk, tenaga kerja, dan input modal kerja lainnya. Yang mana ketiga variabel ini berpengaruh secara negatif terhadap NTP.

Ekspektasi laju inflasi, apalagi jika disertai kenaikan harga BBM, akan menambah biaya pengeluaran masyarakat, tidak terkecuali petani. Ukuran yang paling kasar seperti nilai tukar petani pun telah menunjukkan kecenderungan memburuknya kesejahteraan petani. Nilai tukar petani kumulatif pada Februari 2012 tercatat 105,1 (turun 0,60 persen) dengan gambaran tidak baik diderita petani padi (turun 1,02 persen), nelayan (turun 0,39 persen), dan petani hortikultura (turun 0,23 persen)

Persoalan klasik di lapangan belum dapat ditanggulangi, seperti kenaikan harga faktor produksi pertanian, yaitu pupuk, pestisida, upah buruh, sewa lahan, dan lain-lain, karena akses yang tidak terlalu baik. Apalagi, dengan drama wacana kenaikan harga BBM, petani dan nelayan semakin sulit memeroleh bahan bakar sekadar untuk menyambung hidup karena spekulasi dan penimbunan yang marak terjadi. Tidak terlalu aneh walaupun laju inflasi nasional pada Februari 2012 tercatat 0,05 persen, laju inflasi di daerah 
pedesaan justru menembus 0,46 persen karena semua indeks kelompok pengeluaran naik.

Tidak perlu disebut lagi bahwa penguasaan lahan petani Indonesia sangat tidak merata karena sebanyak 53 persen dari 17,8 juta rumah tangga petani padi-palawija hanya menguasai lahan 0,5 hektar atau kurang. Petani skala kecil ini benar-benar menjadi salah satu kelompok yang sangat rentan terhadap perubahan pengeluaran, apalagi jika harus menanggung tambahan beban kenaikan harga BBM yang berwujud dari biaya transportasi, biaya produksi, sampai pada kebutuhan sehari-hari (Arifin 2012).

Gambar 2. Peningkatan Pendapatan

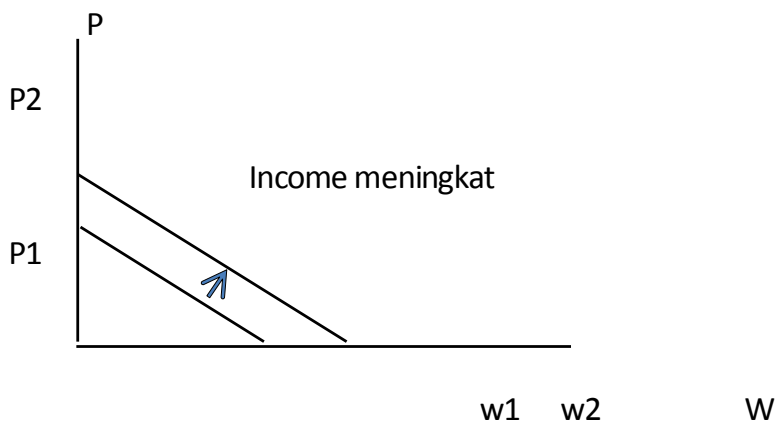

Kenaikan BBM, menyebabkan harga bahan pangan meningkat, pendapatan petani juga meningkat, NTP naik. Isu BBM naik, terjadi psicology effect, spekulasi dan penimbunan, bahan bakar langka menyebabkan harga bahan pangan juga ikut naik, y meningkat. NTP naik.

Gambar 3. Peningkatan Harga Konsumsi

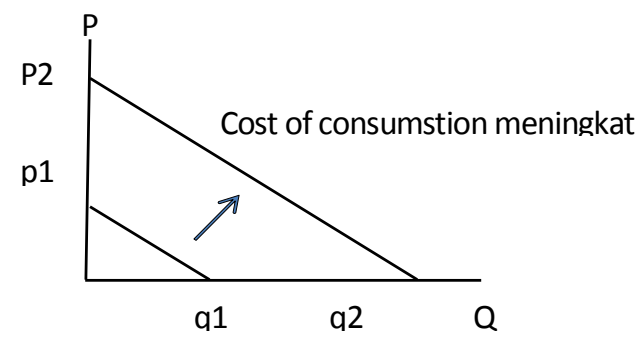


Di sisi lain Ketika terjadi BBM, p meningkat menyebabkan biaya petani untuk mengkonsumsi dan memproduksi juga naik, NTP turun. Isu BBM naik, terjadi psicology effect, spekulasi dan penimbunan, bahan bakar langka menyebabkan barang-barang menjadi mahal termasuk transportasi juga barang-barang untuk produksi tani, NTP turun.

Dari kedua kurva di atas dapat disimpulkan bahwa IT (penerimaan petani dari hasil produksi) jumlahnya tidak lebih besar daripada IB (pengeluaran petani untuk konsumsi dan produksi). IT $<\mathrm{IB}$, hal ini menyebabkan nilai tukar petani pangan menurun, mengakibatkan kesejahteraan petani menurun.

\section{Potensi Pembiayaan Syariah terhadap Nilai Tukar Petani (NTP)}

Menurunnya tingkat pembiayaan terjadi baik dari pihak petani yang merasa dirugikan dengan bunga yang tinggi, ataupun dari pihak perbankan atau BPR yang takut untuk memberi pembiayaan yang terlalu berisiko dan rentan terjadi kredit macet. Hal ini menyebabkan tingkat produktivitas produk pertanian rendah sedangkan konsumsi pribadi para petani terus meningkat. Akibatnya indeks yang diterima petani lebih kecil dari pada indeks yang dibayar sehingga yang terjadi NTP menurun, artinya kesejahteraan petani juga ikut menurun.

Sektor pertanian yang tumbuh subur di Indonesia tidak diiringi dengan kemakmuran rakyat Indonesia. Hal ini dapat dilihat dari sebagian besar petani yang masih melarat. Banyak hal yang menyebabkan hal ini terjadi, seperti petani yang masih menjual hasil panennya kepada tengkulak dengan harga yang sangat murah, tidak adanya biaya modal untuk meneruskan pertanian setelah panen, dan gagalnya panen akibat musibah karena wabah hama maupun bencana alam.

Untuk membantu usaha tani supaya tidak mengalami kerugian, pemerintah membantu dengan meminjamkan modal kepada para petani melalui Bank Perkreditan Rakyat (BPR). Dengan adanya BPR, petani yang 
mengalami kerugian panen akibat musibah dapat kembali bertani dengan meminjam modal. Tentunya pinjaman ini akan dikembalikan setelah petani mendapatkan keuntungan dari hasil panennya. Namun kebanyakan BPR menimpakan bunga terhadap modal yang dipinjamkan petani, walaupun memang bunga tersebut tidak sebesar bunga yang diberikan para tengkulak kepada petani.

Masalah di atas timbul karena adanya bunga, padahal apabila skim kredit pertanian berbasis pada tingkat suku bunga yang harus dikembalikan pada jatuh tempo, akan menjadi tidak efektif. Masalahnya petani memiliki risiko kegagalan yang tinggi baik dalam produksi maupun fluktuasi harga sehingga mereka tidak akan mampu membayar pinjaman sehingga dapat terjerat hutang yang semakin bertambah banyak. Ini menunjukkan adanya kesenjangan dalam 'ruang usaha' antara peminjam dalam hal ini petani dengan pemberi pinjaman yaitu lembaga keuangan. Untuk mengatasi adanya kesenjangan (gap) tersebut, perlu adanya model alternatif pembiayaan yang sesuai dengan karakteristik usaha di sektor pertanian, salah satunya adalah model pembiayaan pertanian dengan skim syariah.

Sayangnya pembiayaan seperti Salam, sesuatu hal yang bermanfaat tersebut masih sangat minim diterapkan di negeri kita ini. Bank syariah yang berdiri di negara kita tak sebanyak bank konvensional. Orang-orang Indonesia pun tak banyak yang menaruh modal pada sektor pertanian. Hal ini banyak sebabnya, salah satunya adalah ketakutan kalau-kalau usaha tani ini mengalami kegagalan sehingga penanam modal pun bisa mengalami kerugian. Karena tidak mau mengambil risiko, penanam modal pun hanya ingin menanamkan modalnya pada komoditi pertanian yang bernilai jual tinggi. Pemerintah seharusnya mendukung penuh konsep pembiayaan Salam ini tidak hanya melalui bank syariah melainkan juga melalui para pemodal, sehingga petani tidak ditindas para tengkulak. 


\section{Simpulan}

Dari pembahasan di atas, dapat disimpulkan sebagai berikut. Pertama, NTP naik tidak selalu baik. Kenaikan NTP pada sektor pangan perlu dilihat apakah produktivitas hasil komoditas memang mengalami kenaikan signifikan. Bisa jadi malah kebalikannya terjadi penurunan produksi akibat anomali cuaca yang mengganggu produksi. Salah satu penyebab turunnya nilai tukar petani pengan adalah terjadi eksploitasi oleh pemilik modal kepada petani, sehingga mereka terpaksa menjual gabahnya dengan harga yang sangat murah.

Kedua, penentu terjadinya kenaikan dan penurunan nilai tukar petani padi adalah produktivitas, harga gabah, harga barang konsumsi, dan harga pupuk. Sedangkan faktor dan penentu lainnya hampir sama yaitu nilai tukar petani terhadap konsumsi makanan dan nonmakanan, serta biaya produksi seperti upah, modal kerja dan input pupuk. Kenaikan BBM berpengaruh negatif terhadap turunnya NTP, akibat naiknya harga barang-barang pokok, termasuk transportasi.

Ketiga, ada tiga permasalahan yang bisa mengancam kesejahteraan petani atas ketidakefektivitas kredit/ peminjaman yaitu pinjaman berbasis bunga, ketimpangan antara peminjam dan pemberi pinjaman serta kurangnya pinjaman kepada sektor pertanian karena dianggap berisiko tinggi.

Keempat, terjadinya permasalahan pembiayaan menyebabkan sulitnya akses biaya produksi sehingga yang terjadi menurunnya tingkat produktifitas dan menurunnya nilai tukar petani, sehingga yang terjadi menurunnya tingkat kesejahteraan petani. Maka perlu mencari alternatif baru untuk membantu sektor pertanian yaitu dengan skim syariah yang bebas bunga dan berdasarkan bagi hasil.

Beberapa implikasi dari hasil penelitian ini adalah sebagai berikut. Pertama, pertanian merupakan hal yang sangat penting untuk diperhatikan di

Economica: Jurnal Ekonomi Islam - Volume 9, Nomor 1 (2018) 
Indonesia, karena Indonesia merupakan negara yang kaya akan sumber daya alam. Sebenarnya cara yang paling jitu untuk memajukan negara ini adalah melalui sektor pertanian. Kedua, pemerintah sebaiknya tidak hanya mensubsidi pupuk kepada petani, tapi juga mensubsidi alat pengolahan gabah, sehingga petani tidak lagi menjual hasil pertaniannya kepada tengkulak. Ketiga, masih kurangnya skim pembiayaan dalam sektor pertanian karena high risk. Sebaiknya pemerintah membuat bank yang khusus bergerak pada bidang pertanian dengan konsep syariah, yaitu bank pertanian syariah. Keempat, pihak bank harus mempunyai sumber daya manusia (SDM) yang memahami masalah pertanian sehingga bisa membaca/memprediksi cuaca, situasi dan kondisi serta mampu memberi solusi kepada petani..

\section{Daftar Pustaka}

Antonio, Muhammad Syafii. 2001. Bank Syariah: Dari Teori Ke Praktik. Jakarta: Gema Insani Press.

Ariffin, Noraini Mohd, Simon Archer, and Rifaat Ahmed Abdel Karim. 2009. "Risks in Islamic Banks: Evidence from Empirical Research." Journal of Banking Regulation 10 (2). Palgrave Macmillan UK: 153-63. https://doi.org/10.1057/jbr.2008.27.

Arifin, Ansar. 2012. "Nelayan Dalam Perangkap Kemiskinan (Studi Strukturasi Patron-Klien Dan Perangkap Kemiskinan Pada Komunitas Nelayan Di Desa Tamalate, Kec. Galesong Utara, Kabupaten Takalar, Provinsi Sulawesi Selatan)." Universitas Hasanudin. http://repository.unhas.ac.id/handle/123456789/1478.

Ashari, NFN, and NFN Saptana. 2005. "Prospek Pembiayaan Syariah Untuk Sektor Pertanian." Forum Penelitian Agro Ekonomi 23 (2): 132-47. https://doi.org/10.21082/fae.v23n2.2005.132-147.

Darwanto, Dwidjono H. 2005. "Ketahanan Pangan Berbasis Produksi Dan Kesejahteraan Petani." Ilmu Pertanian 12 (2): 152-64.

Hendayana, Rachmat. 2002. "Analisis Faktor-Faktor Yang Mempengaruhi Nilai Tukar Petani." SOCA: Journal of Socio-Economic of Agriculture and Agribusiness 2 (2). 
Ilham, Nyak, Hermanto Siregar, and D. S. Priyarsono. 2016. "Efektivitas Kebijakan Harga Pangan Terhadap Ketahanan Pangan." Jurnal Agro Ekonomi 24 (2): 157. https://doi.org/10.21082/jae.v24n2.2006.157177.

Pasaribu, Sahat M., Bambang Sayaza, Jefferson Situmorang, Wahyuning K. Sejati, Adi Setyanto, and Juni Hestina. 2007. "Analisis Kebijakan Pembiayaan Sektor Pertanian." Jakarta: Pusat Analisis Sosial Ekonomi dan Kebijakan Pertanian Badan Penelitian dan Pengembangan Pertanian Departemen Pertanian.

Rachmat, Muchjidin. 2000. "Analisa Nilai Tukar Petani Indonesia." Institut Pertanian Bogor.

Ristek. 2009. Sains Dan Teknologi 2: Berbagai Ide Untuk Menjawab Tantangan \& Kebutuhan. Jakarta: PT. Gramedia Pustaka Utama.

Ruauw, E. 2010. "Nilai Tukar Petani Sebagai Indikator Kesejateraan Petani." Universitas Samratulangi, Manado. ASE 6 (2): 1-8.

Saputra, Hendra. 2012. "Getirnya Menjadi Petani." 2012. https://www.kompasiana.com/hendra.saputra/550f39c4a33311aa2db a8354/getirnya-menjadi-petani.

Sunarti, Euis, and Ali Khomsan. 2006. Kesejahteraan Keluarga Petani Mengapa Sulit Diwujudkan? Institut P. Bogor.

Suntoro, Suntoro, Hery Widijanto, Sudadi Sudadi, and Eko Eri Sambodo. 2014. "Dampak Abu Vulkanik Erupsi Gunung Kelud Dan Pupuk Kandang Terhadap Ketersediaan Dan Serapan Magnesium Tanaman Jagung Di Tanah Alfisol." Sains Tanah - Journal of Soil Science and Agroclimatology 11 (2): 69-138. https://doi.org/10.15608/stjssa.v11i2.222.

Syukur, Mat, Sumaryanto, and Chaerul Muslim. 1993. "Pola Pelayanan Kredit Untuk Masyarakat Berpendapatan Rendah Di Pedesaan Jawa Barat." Forum Penelitian Agro Ekonomi 11 (2): 1-13.

Tampubolon, SMH. 2002. Suara Dari Bogor: Sistem \& Usaha Agribisnis (Kacamata Sang Pemikir). Edited by Harianto, Rachmat Pambudy, Tungkot Sipayung, and Burhanuddin. Bogor: Pusat Studi Pembangunan IPB dan USESE Foundation.

Winangun, Y. Wartaya. 2004. Tanah Sumber Nilai Hidup. Yogyakarta: Penerbit Kanisius.

Economica: Jurnal Ekonomi Islam - Volume 9, Nomor 1 (2018) 
